

\title{
International Control of Aviation
}

$\mathrm{T}$ $\mathrm{HE}$ prominence which the question of air raids and air defence is receiving affords a timely reminder both of the extent to which aviation is rather an international than a national problem, and of the way in which this new power of flight has become rather a menace than an aid to civilisation. A memorandum*, and also one of the six projected handbooks dealing with air raid precautions, have recently been issued by the Air Raid Precautions Department of the Home Office†. In a general preface to the handbook it is explained that measures for safeguarding the civil population against the effects of air attack have become a necessary part of the defensive organisation of any country which is open to air attack, and that the need for them does not arise from any belief that war is imminent. The risk of attack from the air, however remote it may be, is a risk which cannot be ignored, and preparations to minimise the consequences of such attack cannot be improvised on the spur of the moment, but must be made, if they are to be effective, in time of peace.

The handbooks are designed to describe a scheme of precautions which it is hoped would prove effective in preventing avoidable injury and loss of life or widespread dislocation of national activities, and endeavour to give the best available information on methods of passive defence against air attack. The handbook before us is intended primarily for the use of those who in a war emergency would be engaged on first-aid

- Air Raid Precautions. Memorandum No. 1 : Treatment of Casualties and Decontamination of Personnel. (Issued by the Home Office Air Raid Precautions Department.) Pp. 15. (London : H.M. Stationery Office, 1935.) 4d. net.

$\dagger$ Air Raid Precautions. Handbook No. 2: Anti-Gas Precautions and First Aid for Air Raid Casualties. (Issued by the Home Office,
Air Raid Precautions Department.) Pp. 110. (London: H,M. Stationery Office, 1935.) $6 d$. net. services for the civil population, especially members of the St. John Ambulance Brigade, the St. Andrew's Ambulance Association and the British Red Cross Society. It contains a sufficient account of the chemical agents likely to be used and the methods by which they might be distributed to enable such persons to appreciate the dangers to which they would be exposed, as well as adequate informatior on general principles with regard to protection against gas. Steps to be taken for the protection of rooms, etc., against gas, the use of respirators and protective clothing and the treatment of various types of casualties are detailed, as well as measures for the decontamination of personnel and material.

Both the matter and the general principle underlying the publication of these handbooks have already received severe criticism. In the first place, it has been pointed out that the precautions described in the handbook are quite inadequate to confer any real protection. At a recent conference in London it was strongly maintained that it would be impossible adequately to protect a large civil population during a gas attack, or prevent them receiving injuries afterwards from, for example, mustard gas lingering in different places.

It is true that the handbook only professes to deal with avoidable injury, but any attempt in this way to minimise risk may easily create a feeling of false security and encourage the belief that the danger can be entirely avoided. This risk has probably been responsible for opposition from those who emphasise the impossibility of affording civilians the same protection as the services because of the enormous cost. A statement signed by Sir F. G. Hopkins and a number of 
other men of science, and issued by the National Peace Council, takes this view. Adequate defence must provide security against the simultaneous, and not merely the independent, use of high explosive bombs, incendiary bombs and gas attacks. It is necessary to insist that, however wise the proposed measures may be in themselves, the only adequate defence against air warfare is the abolition of war itself, and to point out the danger of allowing precautions or palliatives to divert attention from the main objective.

It is very generally accepted that abolition of national military and naval forces could not be achieved without the international control of civil aircraft, and the more reasonable it is for the British Government or any other Government to consider the means of protecting the civil population from air attack, the more imperative it is that the means of introducing international control should be explored. Equally desirable is the careful examination of the practicability of establishing an international air police force such as has received forceful advocacy of late.

The many questions which arise out of these proposals, such as the relation of an international force to the League of Nations, the technical difficulties to be overcome or the methods of preventing misuse of civil aviation, merit close and scientific study; it may well prove that along these lines will be found the only adequate safeguard and security for all nations. Scientific workers have a special responsibility for assisting in bringing to bear on all such questions an unprejudiced mind and the careful and impartial scrutiny of every factor involved which should be characteristic of the scientific mind.

Inevitably the study of the problem of the air from this point of view leads to the consideration of the whole problem of the future peaceful development of civil aviation. It would be difficult indeed to find a more signal example of the frustration of science than is afforded by aviation, and it is inconceivable that the development either of an international air police force or of international control of civil aircraft could be more inimical to development than the national jealousies and obstructions hitherto in vogue. The effect of these was strikingly demonstrated in the able report on the economics of air transport in Europe recently submitted by M. Henri Bouchée to the special sub-committee of the Air Transport Co-operation Committee of the League of Nations.
The substitution of a single International Air Board of Control under the League of Nations for the twenty-six different controls now exercised by the separate States of Europe alone would remove many hindrances to the development of civil aviation, including restrictions on design, flying lanes and prohibitions to engage in entrepôt trade, and would provide far greater stimulus than is possible under the present conditions of national sovereignty. The powerful plea advanced by $\mathbf{M}$. Bouchée for collective action, calculated on a European scale to meet European needs and based on strictly economic lines, utilising subsidies in a manner enabling air transport to establish itself once and for all, and affording aviation the freedom which is natural to it but which as yet it has neither demanded nor received is, however, only one aspect of the question.

The technical problem in civil aviation is equally important, and here the whole development of civil aviation has been warped from the start through the influence of the War. But for that factor, as Colonel Moore-Brabazon has pointed out, aviation might have developed along different lines, quietly and efficiently, and civil aviation might have played the important part it is meant to do in intercommunication, the military side lagging behind. As a result of wartime development, civil aviation has become no more than an off-shoot of the great military organisations in various countries, and only in Great Britain and the United States can it be said that aviation has been allowed to develop free from direct military influence.

The Diesel engine provides a conspicuous example of the ulterior effect of military influence on civil aviation. From the civil point of view, the Diesel engine has many advantages, notably in burning a fuel of high flash-point and the price of which in Great Britain is less than half that of petrol. This engine, however, is of little interest for military purposes because its performance is not so good as that of the petrol engine and it is also heavier. Since the major outlook for a new type of machine depends on its possibilities for military uses, there is little inducement for the manufacturer to develop the Diesel engine, although there is no type of transport for which the petrol engine is more fundamentally unsuitable than for the aeroplane with its load of inflammable fuel.

If civil aviation is to develop to the full and render its due service to mankind, it must be 
freed completely from military influence, whether technical or economic. The root of the problem lies in the conflict between the conceptions of sovereignty of the air and freedom of the air. Only as the latter conception triumphs can humanity hope that aviation will progress as an instrument not of war but of peace. Scientific workers can never rest content with the mere precautionary methods outlined in the handbooks and policy of the Air Raid Precautions Department. They can indeed contribute something to see that the precautions, so far as they go, are technically sound and are fairly and not unfairly criticised. They fail in their duty, however, if they do not also continue to point out that the only adequate defence or security against air attack lies in the abolition of war itself and in liberating aviation from the bonds imposed on it by the narrow nationalism expressed in the Air Convention of 1919, and clothing it with the freedom of service in which were conducted those technical and scientific investigations which first gave it birth.

\section{The Changing World of the Ice Age}

The Changing World of the Ice Age By Prof. Reginald Aldworth Daly. (Yale University : Mrs. Hepsa Ely Silliman Memorial Lectures.) Pp. $\mathrm{xx}+271+8$ plates. (New Haven, Conn. : Yale University Press; London: Oxford University Press, 1934.) 22s. 6d. net.

$\mathrm{I}^{\mathrm{N}}$ this book Prof. Daly has reprinted the Silliman Lectures for 1934 which he delivered at Yale University to "an audience with a varying knowledge of the facts and principles of geology". But to make the book of greater value to more serious students, the lectures have been somewhat expanded. The author had a threefold aim : (1) to picture the remarkable effects of the Pleistocene glaciations and deglaciations upon the sea-level all over the world; (2) to illustrate some of the no less extraordinary changes in the geography of the regions that were heavily glaciated during the Ice Age ; $(3)$ to discuss the behaviour of the solid earth when it was loaded with the ice-caps and then relieved of those loads by melting and evaporation.

The book is divided into seven sections. A very large amount of material has been used, and many of the facts and instances cited are not easily found elsewhere because of the difficulty of access to many of the publications and the difficulty of reading some of the less-familiar languages in which they are written. At the outset, it may be said that the author accepts a number of hypotheses which some observers are not prepared to adopt, but he never misleads his readers into the supposition that these views are of unanimous acceptance.

In the first section, past and present ice-caps, their measurement and weights are described. Then the sequence of glaciations is considered and the author, while accepting the four glaciations of
Penck and others, in Europe and America, lays stress upon the long duration of the second interglacial phase and its separation of the first twin glaciation from the second twin glaciation. These two peaks of climatic change in the glaciated tracts corresponded with two major pluvial stages in regions now relatively desert, and also with two major periods of deposition of loess in different continents. These climatic rhythms affected simultaneously the whole surface of the earth. An estimate of the duration of the Ice Age is given as nearly one million years. These considerations lead up to the urgent question of what caused the Ice Age ; the author is frankly in doubt and confesses that the subject is still in the state of speculation and remains to him a baffling mystery.

The second section of the book will probably be of greater interest to European readers than are the remaining sections, for it deals with the recession of the Fennoscandian ice sheets; and especially to students of prehistory, for postpalæolithic man has left determinable evidences of sequences of culture in relation to geological changes all round the Baltic shores.

Pleistocene changes in the geography of northern Europe are registered largely by the marks left by the waves of the ocean that kept shifting its level, both up and down, all over the earth. It is not, perhaps, generally realised to what an extent the robbery of water from the oceans during the maximum glaciation depressed the general level of the sea; the author shows that the amount was probably as much as 90 metres all over the earth; and even during the last glaciation, a sinking of some 75 metres was attained. But he warns his readers against supposing that in the warmest interglacial stage the sea-level was higher than it is at present by more than a few tens of metres; and further, that the 